\title{
Actions of the Family Health Strategy Program in the context of family violence against women: A viewpoint from Nursing
}

\author{
Raquel Maria de Sena ${ }^{1}$, Maria Guadalupe de Morais Musa Carballo ${ }^{2,}$ Arabela \\ Alves de Souza ${ }^{3}$, Maria Teresa dos Santos Guedes ${ }^{4}$, Mônica Aparecida Porto \\ Marysse Lanes $^{6}$, Ana Claúdia Frazão Paiva ${ }^{7}$, Teresa Cristina Silva Palermo ${ }^{8}$ \\ 1, 4, 5, 6, 7, 8 (Oncologic Nurses, Outpatient Clinic of the Brazilian National Cancer Institute) \\ ${ }^{2,3}$ (Primary Care Nurses, Course in Family Health Management)
}

\begin{abstract}
Objectives: Identify the actions of the Family Health Strategy Program regarding violence inflicted on women and describe the influencing aspects of these actions using the National Policy of Combating Violence against Women as reference.

Methods: Narrative review of literature. Data collected at the BDENF and LILACS databases. Ten papers were selected for analysis from the period 2013 to 2016.

Results: As to the identification of the actions of the Family Health Strategy Program, 70\% of the studies observed the importance of the link between professionals and users; 60\% of articles show established bond through dialogic listening; $10 \%$ report that this bond depends on the reception given to women in situations of violence.

Conclusion: It was inferred that it is important for nurses to take care of and provide care for women victims of family violence in the Basic Health Units. Nurses have in their training the competence to plan a humanized and safe care, with the ability to build links and bonds with the user, thus allowing understand and identify women's violence as a public health problem, but there is a great need for investments in public health services and professional training to raise awareness and identification of women who suffer violence.
\end{abstract}

Keywords: Violence; Violence against women; Women's health; Family Health; Domestic violence; Public policy; Family Health Strategy Program.

\section{Introduction}

According to the Intramerican Convention to Prevent, Punish and Eradicate Violence against Women Convention of Belém do Pará / ONU, it is considered as violence against women any act based on gender, that causes death, harm or physical, sexual or psychological suffering To women in both the public and private spheres. Violence against women is considered a universal phenomenon that affects all social classes, ethnic group, religions and cultures at any level of economic and social development.

It is believed that the issue of gender becomes extremely important. In this aspect, there are definitions of roles that are heavily subsidized by cultural issues, in which submission is considered a prerequisite for women, placing man in a clear frame of domination related to decision making and problem solving through the imposition of fear. In this context, current statistical studies indicate that being a woman can be a serious risk factor for violence and, according to the World Health Organization (WHO), between 2006 and 2010 Brazil was among the 10 countries with the highest number of female homicides. It should be noted that the main aggressor, according to the mentioned study, has been the men with whom, in most cases, the victim maintains an affective relationship.

In recent years, in Brazil it has been noted the commitment of the different public sectors to prevent violence, focusing on their determinants. Focusing attention on vulnerable groups, with strategic actions resulting from interactions of social movements, involving government policies, programs and legislation, covering the social, legal and health spheres.

Currently, the Third National Policy Plan for Women - 2013-2015 (III NPPFW) is in force in Brazil, a document prepared by the Secretariat for Women's Policy. In this plan, they insert the national policy to combat violence against women and have as objectives: the reduction of all forms of violence against women, guaranteeing their rights, as well as guaranteeing the applicability of the Maria da Penha Law through the strengthening of protection for humanized and integral assistance, as well as promoting their autonomy in pursuit of their rights.

In this context, since the launch of the III NPPFW, the Family Health Strategy Program (FHSP) has a relevant role in addressing the problems related to violence against women, fulfilling the various demands presented by users, in order to organize the management of continuous and permanent care, thus developing multiprofessional, integrated and resolving actions in accordance with Unified Health System (UHS) principles. 
Given the relevance of the topic, the present study aimed to develop a review of the literature, with the objectives of identifying the actions of the FHSP in relation to violence inflicted on women and describing the influencing aspects of these actions using the National Policy of Combating Violence against Women as reference.

\section{Methodology}

It is a narrative review of literature, which is appropriate to describe and discuss the development of a particular subject, which in the present study is violence against women and the Family Health Strategy Program. The references related to the subject were searched in the Virtual Health Library Database and Latin American and Caribbean Literature in Health Sciences (BDENF and LILACS in Portuguese respectively), from 2013 to 2016. For the search we used combinations of the descriptors violence; violence against women; women's health; family health; domestic violence; public policy. The references in the Brazilian Portuguese language were selected. Summaries and full texts available on the above bases have been read. Articles that were not available in full or which were repeated, were not included.

\section{Results And Discussion}

Ten articles were selected for analysis, according to established criteria. The search in the period from 2013 to 2016, with the selected descriptors, matched ten results. The articles selected were all published in the year 2013. In 2013 four publications were from the same main author, all qualitative studies, published in different journals (Table 1).

TABLE 1- Characterization of publications according to the year of publication, author / title, periodicals and methodology.

\begin{tabular}{|c|c|c|c|c|}
\hline $\mathbf{N}$ & YEAR & AUTHOR/TITLE & JOURNAL & METHODOLOGY \\
\hline 1 & 2013 & $\begin{array}{l}\text { M. K. Durand and I.T.S.B. Heidemann. Promotion of the } \\
\text { autonomy of women in the nursing consultation in family } \\
\text { health. }\end{array}$ & $\begin{array}{l}\text { Journal of Shool of } \\
\text { Nursing - University of } \\
\text { São Paulo }\end{array}$ & Qualitative research \\
\hline 2 & 2013 & $\begin{array}{l}\text { N.P.Gomes, A.L.Erdmann, J.B. Carneiro et al. Health } \\
\text { professionals meaning the permanence of women in the } \\
\text { relationship of conjugal violence. }\end{array}$ & $\begin{array}{l}\text { Northeast Network } \\
\text { Nursing Journal }\end{array}$ & Qualitative research \\
\hline 3 & 2013 & $\begin{array}{l}\text { E. B. Silva, S.M.M Padoin and L.A.C Vianna. Violence } \\
\text { against women: limits and potential of care practice. }\end{array}$ & Acta Paul Enferm & Qualitative research \\
\hline 4 & 2013 & $\begin{array}{l}\text { N. P. Gomes, A. L. Erdmann, L.A. Bettinelli et al. Meaning } \\
\text { of professional training for the care of women victims of } \\
\text { conjugal violence. }\end{array}$ & $\begin{array}{l}\text { Anna Nery Nursing } \\
\text { School Magazine }\end{array}$ & Qualitative research \\
\hline 5 & 2013 & $\begin{array}{l}\text { R. N. Guedes, R. M.G.S. Fonseca and E. Y. Egry. Limits } \\
\text { and evaluation possibilities of the family health strategy for } \\
\text { gender violence. }\end{array}$ & $\begin{array}{l}\text { Journal of Shool of } \\
\text { Nursing - University of } \\
\text { São Paulo }\end{array}$ & Qualitative research \\
\hline 6 & 2013 & $\begin{array}{l}\text { N. P. Gomes, Y. M. Silveira, N. M.F. Diniz et al. } \\
\text { Identification of violence in the conjugal relationship based } \\
\text { on the Family Health Strategy Program. }\end{array}$ & $\begin{array}{l}\text { Text \& Context } \\
\text { Nursing }\end{array}$ & Qualitative research \\
\hline 7 & 2013 & $\begin{array}{l}\text { R.S.Aguiar. Nursing care for women victims of domestic } \\
\text { violence. }\end{array}$ & RECOM & Integrative Review \\
\hline 8 & 2013 & $\begin{array}{l}\text { L. Z. Hesler, M. C. Costa, D.G. Resta et al. Violence against } \\
\text { women from the perspective of community health agents. }\end{array}$ & $\begin{array}{l}\text { School of Nursing of } \\
\text { the Universidade } \\
\text { Federal do Rio Grande } \\
\text { do Sul }\end{array}$ & Qualitative research \\
\hline 9 & 2013 & $\begin{array}{l}\text { M. E. F. Quadros, M. M. Oliveira, R. Z. Ferreira and P. F. } \\
\text { Alves. Domestic violence: characterization and attitude of } \\
\text { the family health team regarding the problematic }\end{array}$ & $\begin{array}{l}\text { Journal of Nursing of } \\
\text { the Federal University } \\
\text { of Santa Maria }\end{array}$ & Qualitative research \\
\hline 10 & 2013 & $\begin{array}{l}\text { N. P.Gomes, A. L. Erdmann, J. L.G.Santos et al. Care for } \\
\text { women in situation of conjugal violence: Theory based on } \\
\text { data. }\end{array}$ & $\begin{array}{l}\text { On line Brazilian } \\
\text { Journal of Nursing }\end{array}$ & Qualitative research \\
\hline
\end{tabular}

These results demonstrate that the subject has been studied in the academic environment during courses of Stricto sensu of the Brazilian universities. Such studies can raise the awareness of nursing professionals in training, offering the same subsidies to understand the complexity behind the violence inflicted on women in order to facilitate the recognition and confrontation of it in health services, with emphasis on promotion measures and health education from the perspective of prevention. Table 2 provides an overview of the articles selected for this review. 
TABLE 2 - Summary of the literature review.

\begin{tabular}{|c|c|}
\hline Author & Summary \\
\hline $\begin{array}{l}\text { M. K. Durand and } \\
\text { I.T.S.B. Heidemann, } \\
2013 .\end{array}$ & $\begin{array}{l}\text { It aimed to understand if the nursing consultation in a Health Center is capable of promoting the autonomy of } \\
\text { women who suffer violence. The study revealed the need for nurses to listen and discuss domestic violence and } \\
\text { the importance of the professional relationship with users in the Nursing Consultation. The study concluded that } \\
\text { the Nursing Consultation can establish an environment for the development of prevention and promotion } \\
\text { actions, which still occur in an inhibited way in Health Centers. It is also worth noting the need for } \\
\text { multiprofessional training to understand conceptual issues and promotion strategies and prevention, expanding } \\
\text { its practices in all spaces of the Unified Health System. }\end{array}$ \\
\hline $\begin{array}{l}\text { N.P.Gomes, } \\
\text { A.L.Erdmann, J.B. } \\
\text { Carneiro et al, } 2013 .\end{array}$ & $\begin{array}{l}\text { The study aimed to understand the meanings attributed by professionals who work in the FHSP on the } \\
\text { permanence of women in the relationship of conjugal violence. It was pointed out in the results that women } \\
\text { remain in the relationship with violence due to the threats suffered, the companion's involvement in drug } \\
\text { trafficking, economic and emotional dependence, the value of marriage, the belief of female submission and } \\
\text { shame. The nurses and the multiprofessional group point to strategies in defense of a life free from violence for } \\
\text { women, thus, it was suggested psychosocial support, educational activities on social construction of gender and } \\
\text { political articulation from the intersectoriality. }\end{array}$ \\
\hline $\begin{array}{l}\text { E. B. Silva, S.M.M } \\
\text { Padoin and L. A.C } \\
\text { Vianna, } 2013 .\end{array}$ & $\begin{array}{l}\text { The authors analyzed the limiting and potentiating situations of the assistance practice of the Family Health } \\
\text { teams to women in situations of violence. It was identified the difficulty of obtaining the report of women who } \\
\text { suffered violence, and of involving it in a care project. Due to the cited difficulty, it was observed that the home } \\
\text { visit and the link between professionals and users are considered fundamental for the reception. }\end{array}$ \\
\hline $\begin{array}{l}\text { N. P. Gomes, A. L. } \\
\text { Erdmann, L.A. } \\
\text { Bettinelli et al, } 2013 .\end{array}$ & $\begin{array}{l}\text { The authors sought to understand the meanings attributed by professionals who work in the FHSP on the } \\
\text { professional training to care for women in situation of conjugal violence. The results obtained were the } \\
\text { difficulty of recognizing the woman's illness and referrals to the referral and counter-referral system. It was } \\
\text { concluded that it is necessary to provide subsidies for the management of women's care, especially in Primary } \\
\text { Health Care. Therefore, training as a strategy to guarantee care is fundamental.. }\end{array}$ \\
\hline $\begin{array}{l}\text { N. P. Gomes, A. L. } \\
\text { Erdmann, L.A. } \\
\text { Bettinelli et al2013. }\end{array}$ & $\begin{array}{l}\text { The purpose of this study was to understand the limits and the evaluation possibilities of the FHSP, regarding } \\
\text { the recognition and confrontation of health needs of women who experience gender violence. It was concluded } \\
\text { that assistance was seen as the most significant limitation of professional practices, that is, in the contemporary } \\
\text { version of medicine limited to providing consultations under medical hegemony. However, there were } \\
\text { possibilities related to the linkage created by the logic of attention established with the FHSP, although } \\
\text { restricted by the limitations of the biomedical model and the absence of specific technologies to deal with } \\
\text { violence. }\end{array}$ \\
\hline $\begin{array}{l}\text { N. P. Gomes, Y. M. } \\
\text { Silveira, N. M.F. Diniz } \\
\text { et al, } 2013 .\end{array}$ & $\begin{array}{l}\text { This study aimed to analyze the process of identification of conjugal violence by professionals of the FHSP. It } \\
\text { was revealed that the identification of conjugal violence occurs during professional care and that the non- } \\
\text { identification of the phenomenon is related to professionals who do not yet understand domestic violence as an } \\
\text { object of health. It was concluded that it is important to listen to the women attending the Primary Health Care } \\
\text { and to establish a link between nurses and other professionals with the user to better identify the problem, which } \\
\text { allows greater visibility of violence and also the adoption of strategies for best confrontation. }\end{array}$ \\
\hline R.S.Agu & $\begin{array}{l}\text { The nurses' performance was verified taking as reference the care provided to women victims of domestic } \\
\text { violence. The conclusion was that nurses should carry out and encourage the following actions to care for the } \\
\text { victims of domestic violence: reception, referrals to the competent organs, building of links and home visits. }\end{array}$ \\
\hline $\begin{array}{l}\text { L. Z. Hesler, M. C. } \\
\text { Costa, D.G. Resta and } \\
\text { I. C. S, } 2013 \text {. }\end{array}$ & $\begin{array}{l}\text { The authors sought to know and understand violence against women from the perspective of the Community } \\
\text { Health Agents included in the FHSP. It was concluded that violence against women happens as a social } \\
\text { construction and in gender inequalities, is also seen as a multifactorial construction. Regarding the care and } \\
\text { confrontation practices, some tools were identified: construction of strategies of care with the team, user and } \\
\text { team link, listening and dialogue with the woman victim of violence. This problem was evidenced as a need for } \\
\text { health and assistance, for the construction of confrontation strategies. }\end{array}$ \\
\hline $\begin{array}{l}\text { M. E. F. Quadros, M. } \\
\text { M. Oliveira, R. Z. } \\
\text { Ferreira and P. F. } \\
\text { Alves, } 2013 .\end{array}$ & $\begin{array}{l}\text { The study aimed to know the characterization and attitude of the family health team in the face of domestic } \\
\text { violence and found that the professionals characterize domestic violence against women as a serious, grave and } \\
\text { important problem in society, however, some feel unable to assist women in this situation. It was also pointed } \\
\text { out that it is necessary to clarify the problem of domestic violence against women so that this situation can be } \\
\text { understood as a problem that is both social and public health, highlighting the difficulties of the professionals } \\
\text { who work in the families care clinics in the raped woman attendance. }\end{array}$ \\
\hline $\begin{array}{l}\text { N. P.Gomes, A. L. } \\
\text { Erdmann, J. L.G.Santo } \\
\text { et al, } 2013 .\end{array}$ & $\begin{array}{l}\text { The study sought to understand the meanings attributed by health professionals on the management of care for } \\
\text { women in situation of conjugal violence within the scope of the FHSP. As results on the meanings found: } \\
\text { appreciation of the users speech, the formation of bond, the creation of spaces for discussion on the subject and } \\
\text { intersectoral articulation with the university. It was concluded that the nurse is fundamental in the process of } \\
\text { organization of the health units, especially for integrating the team and occupy management positions within the } \\
\text { scope of the FHSP. }\end{array}$ \\
\hline
\end{tabular}

Regarding the identification of the actions of the FHSP, it was observed that in the articles analyzed, $70 \%$ of the studies emphasized the importance of a link between professionals and users. It was verified in $60 \%$ of the articles that this link is established through the dialogical listening. $10 \%$ of the studies report that this bond depends on the form of reception that is provided to women in situations of violence.

Pinheiro and Gomes (2005) affirm that reception is translated into the humanized, welcoming relationship, by the workers and the service as a whole, to establish a link between the different types of users. Bonding is the interaction with the subject and can be a link or a bond. Link, is the vehicle of information and bond is established when a common environment is achieved in which the subjects and their knowledge interact and dialogue, generating common actions that support the existence of this meeting space [11]. 
It is noteworthy that in $50 \%$ of the articles, professionals need to understand and identify family violence against women as a public health problem and $20 \%$ of them report the difficulty due to lack of resources to plan strategies against violence for better confrontation.

Violence against women is understood as a problem of Public Health, however, there is a lack of preparation of professionals to identify people in situations of violence and deficits in investments in Public Health services that are related to the identification of women victims [12].

It was evidenced in $20 \%$ of the articles, the need to carry out educational activities for the population and the importance of the FHSP team to carry out frequent home visits. Silva et al. (2013) report that educational activities are all actions that stimulate disease prevention, health promotion and population engagement, and their participation in health and quality of life issues [13].

Cunha and Gama (2012) mention that home visits constitute an instrument of health care that enables, from the knowledge of the reality of the individual and his family in loco, to strengthen patient, therapeutic and professional ties, as well as to act in the health promotion, prevention, treatment and rehabilitation of diseases and injuries. The home visit has been pointed out as an important vehicle for operationalization of part of a health care program or health care policy present in a given historical moment, making possible the achievement of longitudinality, completeness, accessibility and interaction between the professional and the user /family [14]

\section{Final Considerations}

From the literature review, it was inferred that it is important that the nurses act in the reception and care provided to women victims of family violence in the Basic Health Units. The nurse has in her training the competence to plan a humanized and safe care, with the ability to build links and bonds with the user, thus allowing the understanding and identification of family violence against women as a public health problem. However, there is a great need for investments in public health services and professional training for better awareness and identification of women who suffer violence.

\section{References}

[1]. M. K. Durand and I.T.S.B. Heidemann, The promotion of women's autonomy during family health nursing consultations, Revista Esc Enfermagem USP, 47 (2), 2013, 288-95.

[2]. N.P. Gomes, A.L. Erdmann, J.B. Carneiro et al, Health Professionals and themeaning they apply to women's remaining in violent conjugal relationships, Revista da Rede de Enfermagem do Nordeste, 14 (3), 2013, 558-67.

[3]. E. B. Silva, S.M.M Padoin and L. A.C Vianna, Violence against women: the limits and potentialities of care practice, Acta Paul Enfermagem, 26(6), 2013, 608-13

[4]. N. P. Gomes, A. L. Erdmann, L.A. Bettinelli et al, The meaning of professional training for the care of women victims of domestic violence, Revista da Escola de Enfermagem Anna Nery , 17 (4),2013, 683 - 689.

[5]. R. N. Guedes, R. M.G.S. Fonseca and E. Y. Egry, The evalutive limits and possibilities in the Family Health Strategy for genderbased violence, Revista de Escola de Enfermagem USP, 47(2), 2013, 303-9.

[6]. N. P.Gomes, Y. M. Silveira, N. M.F. Diniz, et al., dentification of violence in the conjugal relationship based on the family health strategy, Revista Texto e Contexto Enfermagem, 22(3),2013, 789-96.

[7]. R.S.Aguiar, Nursing care provided to women victims of domestic violence, Revista de Enfermagem do Centro Oeste Mineiro, 3 (2), 2013, 723-731.

[8]. L. Z. Hesler, M. C. Costa, D.G. Resta and I. C. S. Colomé, Violence against women in the perspective of community health agents, Revista Gaúcha de Enfermagem, 34 (1), 2013, 180-186.

[9]. M. E. F. Quadros, M. M. Oliveira, R. Z. Ferreira and P. F. Alves, Characterization and attitude of family healthy team front of the problem, Revista de Enfermagem da UFSM, 3(1), 2013, 164-174.

[10]. N. P.Gomes, A. L. Erdmann, J. L.G.Santos et al, Cuidado à mulher em situação de violência conjugal: teoria fundamentos nos dados, On line Brazilian Journal of nursing, 12(4), 2013, 782-93

[11]. M. C. P. A. Gomes and R. Pinheiro, Acolhimento e vínculo: práticas de integralidade na gestão do cuidado em saúde em grandes centros urbanos, Interface, comunicação, saúde educação, 9(17), 2005, 287-301.

[12]. L. A. M. Cordeiro, S. M. Cordeiro, C. C. .Lima et at, Violenc against women: integrative review, Revista de Enfermagem UFPE, 7, 2013, 862-9

[13]. A. L. Q. C. Silva, L. S. Araújo, Z. S. S. B. Silva et al, Práticas educativas mais utilizadas pelos enfermeiros na atenção básica: Uma revisão bibliográfica, Revista Científica do ITPAC, 6(4), 2013.

[14]. W. Malagutti, Assistência domiciliar - atualidades da assistência de enfermagem (Rio de Janeiro, Rubio, 2012).

Raquel Maria De Sena. "Actions of the Family Health Strategy Program in the context of family violence against women: A viewpoint from Nursing." IOSR Journal of Nursing and Health Science (IOSR-JNHS) 6.4 (2017): 42-45. 